\title{
(2. \\ Correlation between albumin serum and frailty in geriatric inpatient and outpatient clinic at Sanglah Hospital Denpasar
}

INTISARI SAINS MEDIS

Published by Intisari Sains Medis

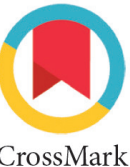

\author{
Putu Shely Prihastuti Rudy ${ }^{1 *}$, RA Tuty Kuswardhani' ${ }^{1}$ I Gusti Putu Suka Aryana' ${ }^{1}$, Nyoman Astika', \\ Ida Bagus Putu Putrawan', Ni Ketut Rai Purnami ${ }^{1}$
}

'Geriatric Division, Department of Internal Medicine, Faculty of Medicine Udayana University / Sanglah Hospital, Denpasar, Bali, Indonesia;

\section{*Corresponding author:}

Putu Shely Prihastuti Rudy;

Geriatric Division, Department of Internal Medicine, Faculty of Medicine Udayana University / Sanglah Hospital, Denpasar, Bali, Indonesia;

putushely@yahoo.co.id

Received: 2021-09-13

Accepted: 2021-12-02

Published: 2021-12-20

\section{ABSTRACT}

Background: Frailty in the elderly has a bad impact on health, especially in the elderly with acute illness. Elderly with frailty has an increase susceptibility to falls, disability and death. Frailty is a common problem in elderly patients, and hypoalbuminemia suggested to increase the risk of death. This study aimed to determine the relationship between albumin and frailty.

Method: A Cross-Sectional Study was conducted from February 2018 to January 2019 at Sanglah Hospital with total 60 patients. Patients were divided into two groups, patients with hypoalbuminemia (albumin $<3.5$ $\mathrm{g} / \mathrm{dL}$ ) and patients with normal serum albumin levels (albumin $\geq 3.5 \mathrm{~g} / \mathrm{dL}$ ). The frailty status assessment was measured with Fried's Frailty Phenotype questionnaire. Chi-square test was used to find the relationship between serum albumin and frailty.
Result: We evaluated 60 patients, 36 patients (60\%) were male and 24 patients (40\%) were female. The age of the study subjects ranged from 62 to 92 years. In this study 26 patients (43.3\%) with hypoalbuminemia and 34 patients (56.7\%) with normal serum albumin. There were 20 patients $(76.9 \%)$ with frailty in the hypoalbuminemia group, compared to 11 patients (32.4\%) in the group of patients with normal serum albumin. Hypoalbuminemia has a risk of 6.97 times greater frailty compared to normal albumin in elderly patients $(p=0.001)$.

Conclusion: This study exhibited a significant relationship between serum albumin and frailty in elderly admitted to inpatient unit and outpatient clinic. The lower the serum albumin level, the higher the probability of the elderly to experience frailty.

Keywords: Serum albumin, frailty, elderly.

Cite This Article: Rudy, P.S.P., Kuswardhani, R.A.T., Aryana, I.G.P.S., Astika, N., Putrawan, I.B.P., Purnami, N.K.R. 2021. Correlation between albumin serum and frailty in geriatric inpatient and outpatient clinic at Sanglah Hospital Denpasar. Intisari Sains Medis 12(3): 897-900. D01: 10.15562/ism.v12i3.1137

\section{BACKGROUND}

There is a high increase in elderly population especially in developing countries in this century. An area is said to have an old population structure if the percentage of elderly is more than $7 \%$. The population of elderly globally is currently experiencing rapid growth and is predicted to continue to increase in the future. The number of elderly has increased worldwide in recent decades. It is estimated that in 2025 the elderly population will be around 1,200 million. The World Health Organization (WHO) estimated that the growth of the elderly population in Indonesia in 2020 would reach $11.34 \%$ or around 28.8 million people. ${ }^{1}$

The increasing life expectancy of the elderly in Indonesia is the impact of successful development along with the increase in the elderly population. This is an implication of improved health and social conditions of the community. However, this condition can be accompanied by an increase in morbidity, and a decrease in the body's physiological functions in the elderly. ${ }^{2.3}$

Albumin is the main component of body plasma protein which is needed to maintain oncotic pressure, microvascular permeability, acid-base balance, and prevent platelet aggregation. ${ }^{4}$ Albumin is often used in screening nutritional status because it is objective and quantitative. Serum albumin is an important parameter to assess the nutritional status of patients with acute and chronic diseases. Hypoalbuminemia is associated with morbidity and mortality in a variety of populations, including patients with acute myocardial infarction, heart failure, stroke, renal disease, hip fracture, and malignancy. ${ }^{4}$ Malnutrition and inflammation suppress albumin synthesis. This process causes an increase amino acids. If the amount is limited from food intake, it will be obtained from the breakdown of skeletal muscle protein. The breakdown of amino acids leads to body weight and muscle mass alteration. Hypoalbuminemia is a biomarker for malnutrition and chronic inflammation, and has been shown to be a risk factor for mortality and morbidity.

The process of degeneration due to increasing age will cause structural changes and a decrease in the function of body systems. Frailty is defined as a 
multidimensional syndrome characterized by the appearance of physiological disorders, decreased function, cognitive impairment, affective disorders, psychosocial disorders and loss of physical abilities with age. Frailty is defined as a loss of the dominant strength of several functions, leading to a decreased storage capacity to handle various stressors. Elderly prone to this condition. ${ }^{5,6}$ The main trait of frailty is the increased vulnerability to stressors due to incompetence in several interrelated systems that lead to decrease in homeostasis. ${ }^{78}$ Frailty in the elderly has a bad impact on health, especially in the elderly with acute illness. Elderly with frailty has an increase susceptibility to falls, disability, depression, weight loss, longer length of stay, immobilization, infection, disability and death. These conditions affect the quality of life of the elderly.,10

Several studies have shown hypoalbuminemia to be a predictor of mortality. Low albumin concentration also correlates with functional status. This study aimed to determine the relationship between serum albumin and frailty in elderly patients at Sanglah General Hospital.

\section{METHOD}

This was a cross-sectional study conducted geriatric population admitted to inpatient unit and outpatient clinic of Sanglah Hospital, Denpasar. The study was conducted from February 2018 to January 2019. Albumin levels were measured based on laboratory tests, while frailty status was assessed using the Fried's Frailty Phenotype questionnaire, which assessed: unplanned weight loss in 1 year $(>4.54 \mathrm{~kg})$; fatigue by evaluating whether more effort was needed to do everything including daily activities in the last week (at least for 3 days) or not being able to travel out of the house in the last week (at least for 3 days); walking speed by asking the patient to walk 15 feet or the equivalent of 4.57 meters and then the time required was calculated; decrease in physical activity based on Minnesota Time Physical Time (18 types of physical activity), low activity if it is $383 \mathrm{kcal} /$ week for men, $270 \mathrm{kcal} /$ week for women; weakness by using a handgrip dynamometer. Frailty was established when the patient met three or more of these five criteria. The study was conducted by simple random sampling from the elderly patients registry in the inpatient unit and outpatient clinic of Sanglah Hospital, Denpasar.

All data were analyzed descriptively, with frequency and percentage for categorical data and mean \pm standard deviation (SD) or median (minimummaximum) for numerical data. All numeric data were assessed its normality using the Kolmogorov-Smirnov test. Chi-square test was used to find the relationship between serum albumin and frailty. A $p$-value of $<$ 0.05 was considered significant.

\section{RESULT}

This study involved 60 study subjects aged over 60 years who visited the internal medicine clinic of Sanglah Hospital with majority of men over women. The

\section{Table 1. Basic Characteristics of Subjects $(n=60)$.}

\begin{tabular}{l|c}
\multicolumn{1}{c|}{ Characteristics } & Value \\
\hline Gender, n (\%) & \\
$\quad$ Men & $36(60)$ \\
Women & $24(40)$ \\
Age, median (minimum-maximum) & $70(62-92)$ \\
Marital status, n (\%) & \\
$\quad$ Not married & $1(1.7)$ \\
Married & $53(88.3)$ \\
Widow & $6(10)$ \\
Profession, n (\%) & \\
Unemployment & $11(18.3)$ \\
Retired civil servants & $5(8.3)$ \\
Private pensioner & $11(18.3)$ \\
Entrepreneur & $5(8.3)$ \\
Farmer & $28(46.8)$ \\
\hline
\end{tabular}

\section{Table 2. Nutritional Variables and Phenotype of Frailty.}

\begin{tabular}{lc}
\hline Characteristics & Value \\
\hline Clinical & \\
Weight (kg), median (minimum-maximum) & \\
BMI (kg/m2), median (minimum-maximum) & $21.87(12.7-26.91)$ \\
Fragility, n (\%) & \\
$\quad$ Yes & $31(51.7)$ \\
No & $29(48.3)$ \\
Albumin & \\
Hypoalbumin & $26(43.4)$ \\
Normal albumin & $34(56.7)$ \\
Phenotype of Frailty & \\
Weight loss & $26(43.3)$ \\
Fatigue & $30(50)$ \\
Decreased Walking Speed & $29(48.3)$ \\
Decreased activity & $30(50)$ \\
Weakness & $46(76.7)$ \\
\hline
\end{tabular}

youngest study subject was 62 years old and the oldest was 92 years old. Most of the subjects were married (88.3\%). A total of 28 subjects $(46.8 \%)$ were farmers, 5 (8.3\%) were remain active entrepreneurs, while the rest were no longer working and have retired from their job as civil servants r private sector employees.

Of the 60 subjects in this study, 26 (43.4\%) had hypoalbuminemia and 34 (56.7\%) had normal albumin. A total of 31 (51.7\%) elderly experienced frailty. Of 31 people who experienced frailty, women. Based on the frailty phenotype, 26 (43.3\%) subjects experienced weight loss, $30(50 \%)$ experienced fatigue, $29(48.3 \%)$ experienced a decrease in walking speed, 30 (50\%) experienced a decrease in activity and $46(76.6 \%)$ experienced weakness.

Based on table 2, it can be seen that 
Table 3. Relationship between Serum Albumin and Frailty in Elderly.

\begin{tabular}{|c|c|c|c|c|c|c|c|c|}
\hline & & \multicolumn{4}{|c|}{ Frailty } & \multirow{3}{*}{ P value } & \multirow{3}{*}{ PR } & \multirow{3}{*}{$95 \% \mathrm{Cl}$} \\
\hline & & \multicolumn{2}{|c|}{ Yes } & \multicolumn{2}{|c|}{ No } & & & \\
\hline & & $n$ & $\%$ & $\mathbf{N}$ & $\%$ & & & \\
\hline \multirow[t]{2}{*}{ Albumin } & Low & 20 & 76.9 & 6 & 23.1 & 0.001 & 6.97 & $2.18-22.26$ \\
\hline & Normal & 11 & 32.4 & 23 & 67.6 & & & \\
\hline
\end{tabular}

from 60 subjects in this study, 26 (43.3\%) had hypoalbuminemia and $34(56.7 \%)$ had normal serum albumin. Among the subjects with hypoalbuminemia, there were 20 (76.9\%) subjects who experienced frailty, compared to 11 (32.4\%) subjects in the group of patients with normal serum albumin. The data analysis showed that subjects with hypoalbuminemia had a 6.97 times higher risk of experiencing frailty compared to subjects with normal albumin $(\mathrm{p}=0.001)$ (Table 3$)$.

\section{DISCUSSION}

Aging is thought to be the result of a lifelong accumulation of molecular and cellular damage caused by multiple mechanisms regulated by a complex network of maintenance and repair affected by genetic, environmental and epigenetic mechanisms. Damages in cellular level leads to organ physiology disorders. In addition, physical activity and nutritional factors cause a loss of cumulative physiological reserves in organ systems and may lead to frailty, characterized by an increased risk of falls, delirium and disability thereby increasing the risk of admission to hospital and accelerate further decline and increase the risk of long-term care. The inflammatory state activates pro-inflammatory cytokines, especially IL-6, IL- 1 and Tumor Necrosis Factor (TNF) which correlate with aging, nutritional status and muscle mass. Although the mechanisms remain unclear, the increase in cytokines results in a progressive decrease in muscle fiber count, weight loss, loss of muscle mass and strength, which correlates with frailty in the elderly. ${ }^{11}$

Study subjects' demographic and the relationship between hypoalbuminemia and frailty in elderly had been showed in this study. Albumin concentration was associated with muscle strength as measured by a handgrip in a transverse study. Several studies have shown that there is a direct relationship between albumin concentration and loss of muscle strength for over two years. ${ }^{12,13}$ The results of this study indicate that there is a relationship between albumin and frailty in the elderly. Both variables have a significant correlation value $(\mathrm{p}=0.001)$. This is in accordance with a previous study by Hong et $\mathrm{al}^{14}$ who explained that frailty was positively related to age, polypharmacy, history of falls, nutritional status, serum albumin levels. Proteinenergy homeostasis is a key determinant of healthy aging. Lower protein intake was associated with a higher prevalence of frailty. Elderly with lower serum albumin levels tend to develop frailty. Previous study conducted by Kim et al. ${ }^{15}$ also showed that there was a close relationship between nutritional status and frailty and an increased risk of mortality in patients with low albumin levels. ${ }^{16}$

Albumin is considered as an independent risk factor for mortality, disability status, thereby it helps to identify frailty in the elderly. ${ }^{16}$ There was an association between high serum albumin levels and a shorter mean length of hospital stay, which means that patients with higher albumin levels have improvement in functional status in shorter treatment periods. ${ }^{17}$ Other studies have shown that low serum albumin levels are important predictors of length of hospital stay, increased complications and causes of death. Gradual increases in mortality with decreasing albumin levels have been demonstrated in several populations with different demographic and health characteristics. ${ }^{18}$

The results of this study showed a relationship between hypoalbuminemia and frailty in the elderly. This study highlighted the utility of serum albumin concentration as a simple marker of frailty and increased mortality in elderly patients. This nutrient- associated biomarkers can be used for early detection of frailty in older patients. Further studies investigating the relationship of other inflammatory markers with frailty in the elderly are warrant. Further studies with a larger sample size are necessary to investigate the relationship between serum albumin and frailty in the elderly associated with various other variables.

\section{CONCLUSION}

This study exhibited a significant relationship between serum albumin and frailty in elderly admitted to inpatient unit and outpatient clinic of Sanglah Hospital, Denpasar. The results showed that the lower the serum albumin level, the higher the probability of the elderly to experience frailty.

\section{CONFLICT OF INTEREST}

All author declare that there is no conflict of interest with regards to this research.

\section{ETHICS CONSIDERATION}

Ethics approval has been obtained from the Ethics Committee of Faculty of Medicine, Udayana University, Sanglah Hospital, Denpasar, Bali, Indonesia, based on COPE protocol prior to the study conducted.

\section{FUNDING}

This study was self-funded by authors without the involvement of grants, scholarships, or any other funding resources.

\section{AUTHOR CONTRIBUTION}

All authors contributed to data analysis, drafting and revising the article, giving final approval of the version to be published, and agreeing to be accountable for all study aspects.

\section{REFERENCES}

1. Chen X, Mao G, Leng SX. Frailty syndrome: an overview. Clinical Interventions in Aging. 2014;9:433-41. 
2. Komisi Nasional Lanjut Usia.Profil Penduduk Lanjut Usia 2009. Jakarta: Komnas Nasional Lanjut Usia; 2010.

3. Pranarka, K. Penerapan Geriatrik Kedokteran Menuju Usia Lanjut yang Sehat. Univ Med. 2006;25(4):187-97.

4. Akirov A, Iraqi HM, Atamna A, Shimon I. Low albumin levels are associated with mortality risk in hospitalized patients. The American Journal of Medicine. 2017;130:1465e11-1465e19.

5. Fried LP, Tangen C, Walston J. Frailty in older adults: evidence for a phenotype. J Gerontol A Biol Sci Med Sci. 2001;56A:M146-M156.

6. McDermid RC, Selfox HT, Bagshaw SM. Frailty in the critically ill : a novel concept. Crit Care. 2011;15:301.

7. Hilmer SN, Perera V, Mitchell S, Murnion BP, Dent J, Bajorek B, et al. The assesment of frailty in older people in acute care. Australas J Ageing. 2009;28:182-8.

8. Bergman H, Ferrucci L, Guralnik J, Hogan DB, Hummel S, Karunananthan S, et al. Frailty: an emerging research and clinical paradigmissues and controversies. J Gerontol A Biol Sci Med Sci. 2007;62(7):731-7.
9. Masel MC, Ostir GV, Ottenbacher KJ. frailty, mortality, and health related quality of life in older mexican americans. J Am Geriatr Soc. 2010;58(11):2149-53.

10. Roman RO, Cathal DW, Brian AL, Rose AK. A frailty instrument for primary care : findings from the Survey of Health, Ageing and Retirement in Europe (SHARE). BMC Geriatrics. 2010;10(57):1471-2318.

11. Hubbard RE. Inflammation and frailty measures in older people. J Cell Mol Med. 2009;13:31039.

12. Schalk BW,Visser M, Penninx BW, Baadenhuijsen H, Bouter LM, Deeg DJ. Change in serum albumin and subsequent decline in functional status in older persons. Aging Clin Exp Res. 2005;17(4):297-305.

13. Snyder CK, Lapidus JA, Cawthon PM, Dam TL, Sakai LY, Marshall LM, et al. Serum albumin in relation to change in muscle mass, muscle strength, and muscle power in older men. J Am Geriatr Soc. 2012;60(9):1663-72.

14. Hong X, Yan J, Xu L, Shen S, Zeng X, Chen L. Relationship between nutrional status and frailty in hospitalized older patients. Clinical Interventions in Aging. 2018;14:105-11.

15. Kim J, Lee Y, Won CW, Lee KE, Chon D. Nutritional status and frailty in communitydwelling older Korean adults: the Korean frailty and aging cohort study. J Nutr Health Aging. 2018;22(7):774-8.

16. Corti MC, Guralnik JM, Salive ME, Sorkin JD. Serum albumin level and physical disability as predictors of mortality in older persons. JAMA. 1994;272:1036-42.

17. Luk JK, Chiu PK, Tam S, Chu LW. Relationship between admission albumin levels and rehabilitation outcomes in older patients. Arch Gerontol Geriatr. 2011;53(1):84-9.

18. Gutiérrez JL, Rangel EI, Luna S. Impact of hypoalbuminemia on survival of frail elderly over 75 years. Med Int Méx. 2016;32(1):27-32.

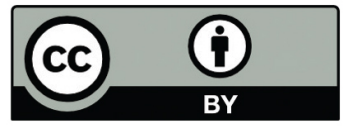

This work is licensed under a Creative Commons Attribution 